\title{
Occurrence of anisakid nematodes in Atlantic cod (Gadus morhua) and Greenland cod (Gadus ogac), West Greenland
}

\author{
Kim N. Mouritsen'1, Rasmus Hedeholm¹, Henriette B. Schack², Lone Nukaaraq Møller³, \\ Marie Storr-Paulsen ${ }^{4}$, Joanna Dzido ${ }^{5}$ and Jerzy Rokicki ${ }^{*}$
}

\author{
${ }^{1}$ Department of Biological Sciences, University of Aarhus, Marine Ecology, Finlandsgade 14, DK-8200 Aarhus N, Denmark; \\ ${ }^{2}$ Department of Biological Sciences, University of Aarhus, Zoophysiology, C.F. Møllers Allé, Building 1131, DK-8000 Aarhus C, Denmark; \\ ${ }^{3}$ Danish Centre for Experimental Parasitology, Faculty of Life Sciences, University of Copenhagen, Dyrlaegevej 100, \\ DK-1870 Frederiksberg C, Denmark; ${ }^{4}$ Danish Institute of Fisheries, Charlottenlund slot, Denmark; \\ ${ }^{5}$ Department of Invertebrate Zoology, University of Gdańsk, Al. Piłsudskiego 46, 81-378 Gdynia, Poland
}

\begin{abstract}
Anisakid nematodes commonly infect gadids, and are of economic and aesthetic importance to the commercial fishing industry in Greenland as some species are pathogenic to humans. However, very little is known about the occurrence of these parasites and their impact on the hosts in Greenland waters. During a survey in 2005, stomach sample of 227 Atlantic cod (Gadus morhua) and 64 Greenland cod (Gadus ogac) was collected in Godthaab and Sisimiut fiord systems in West Greenland waters. All cod were dissected for stomach contents and anisakid nematodes were removed from the visceral cavity. Third stage larvae (L3) of three anisakid species were found, including Contracaecum osculatum (Rudolphi, 1802), Anisakis simplex (Rudolphi, 1809) and Hysterothylacium aduncum (Rudolphi, 1802). Molecular identification by PCR-RFLP indicated the presence of A. simplex s.s. and the sibling species $C$. osculatum $\mathrm{B}$ and C. The prevalence of infection by $C$. osculatum was higher in Greenland cod (84.3\%) than in Atlantic cod (73.9\%) whereas the prevalence of A. simplex showed an opposite pattern (Greenland $\operatorname{cod} 8.3 \%$; Atlantic cod 24.2\%). Only one G. morhua (1.0\%) was infected by H. aduncum. No gender specific difference in both nematode species regarding prevalence of infection and mean infection intensity was evident, and there was no relationship between fish condition and the intensity of nematode infections. Standardised for size, capelin-eating cod were in better condition and more heavily infected than fish subsisting on alternative prey at the point of collection. Hence, nematode infections in the two gadids seem governed in part by feeding behaviour, and capelin appears a significant source of larval anisakids.
\end{abstract}

Keywords

Anisakid larvae, capelin, feeding behaviour, cod, prey choice

\section{Introduction}

Anisakid nematodes are common parasites of the Atlantic cod (Gadus morhua), and are usually found in the viscera and muscle tissue (e.g. Hemmingsen and MacKenzie 2001). The general life cycle of the parasites is initiated when the nematode larvae are eaten by small crustaceans. When infected crustaceans are consumed by fish such as capelin (Mallotus villosus) and gadids, these act as intermediate or paratenic hosts. The life cycle continues when the fish are in turn eaten by mammals such as seals and whales (final hosts). Eggs from the parasites are excreted trough the faeces of the final host directly into the water.
The parasites can be pathogenic to humans when ingested through raw, undercooked or unfrozen fish (Rokicki 2006). Furthermore, their presence in muscle tissue of cod is of economic importance due to the hygienic problems they cause in the fishing industry (McClelland 2002). Also, parasites are usually able to regulate their host population (Begon et al. 1996, Mouritsen and Poulin 2002, Møller 2005) and where these parasitic nematodes occur abundantly they might well affect the cod population negatively. Although the Atlantic cod is of substantial commercial importance also in Greenlandic waters, despite a serious population decline during the recent decades (Storr-Paulsen and Wieland 2006), very little is known about the occurrence or the impact on the host of anisakid nematodes. 
The present paper reports on the occurrence of anisakid nematodes from Atlantic cod in two fiord systems, Godthaab and Sisimiut, in western Greenland in relation to host size, condition and feeding habits.

Parasite prevalence and intensity is usually a positive function of age, due to the increased likelihood of being infected as a function of time (e.g., Polyanskiy 1958, Hays et al. 1998, see also Poulin 2000). However, cod usually express an ontogenetic shift in feeding behaviour from small prey items such as crustaceans to particularly capelin (Nielsen and Andersen 2001, Link and Garrison 2002, present study). Because capelin is an important paratenic or intermediate host for several species of anisakid nematodes (Arthur et al. 1995, Hays et al. 1998), serving to accumulate their infective larval stages, we therefore specifically investigate the hypothesis that increasing parasitism with host size/age is not solely a matter of time but also partly due to changed feeding habits towards more infected prey (Dogiel 1958). We also specifically address the likely hypothesis that increasing nematode infections affect the host negatively. Khan and Chandra (2006) suggested that an overall decline of parasites, including Anisakis sp., in the Labrador population of G. morhua was related to changes in climate conditions, causing absence of capelin as a potential major food source and ultimately a decline in the cod population.

For comparative purpose the co-occurring and parasitologically unstudied Greenland cod (Gadus ogac) is included in the investigation. Furthermore, the species could potentially be of commercial importance as an alternative to the rapidly declining Atlantic cod. In this respect, it would also be of value to gather information of the level of important parasitism in this species.

\section{Materials and methods}

\section{Study sites and sampling}

The study was carried out in 2005 from June 19th to July 9th, off the west coast of Greenland, where 227 Atlantic cod and 64 Greenland cod were sampled and weighted, sexed and measured to the nearest $\mathrm{cm}$. Fish were collected from two main areas: the Godthaab (Nuuk) fiord system (100 Atlantic cod and 36 Greenland cod) and the Sisimiut fiord system (127 Atlantic cod and 28 Greenland cod). These areas are in NAFO division's $1 \mathrm{D}$ (north of $62^{\circ} 30^{\prime}$ and south of $64^{\circ} 15^{\prime}$ ) and $1 \mathrm{~B}$ (north of $68^{\circ} 00^{\prime}$ and south of $68^{\circ} 50^{\prime}$ ), respectively. Both species were sampled throughout both fiord systems (Sisimiut: 27 sites; Godthaab: 17 sites), and fish caught ranged in weight between 20 and 3,890 g and in length from 13 to $69 \mathrm{~cm}$.

Fish were caught using gillnets with five different mesh sizes $(16.5,18,24,28$ and $33 \mathrm{~mm})$. Ten gillnets were combined to add up to $100 \mathrm{~m}$ of net with each of the five different mesh sizes represented twice. The nets were set at four different depth intervals: $0-5 \mathrm{~m}, 5-10 \mathrm{~m}, 10-15 \mathrm{~m}$ and $15-20 \mathrm{~m}$. De- pending on weather conditions, the nets were set to fish for 6.5-12 hrs which ensured at least one tidal cycle during the fishing period. Due to the latitude and time of year the light intensity varied only very little over the diurnal cycle. The nets were thus allowed to fish at all times during the diurnal cycle.

After sorting the catch according to species, the total length of the Atlantic and Greenland cod was measured to the nearest $\mathrm{cm}$ and their weight noted $( \pm 5 \mathrm{~g})$. Fish showing evidence of regurgitation (i.e. stomach content in mouth) or having been partly eaten by scavengers were excluded from the present analysis. The remaining fish were gutted, sexed and the stomach (oesophagus to the pylorus sphincter) was removed and frozen within one hour.

The fish were divided into length classes: $0(0 \mathrm{~cm}), 1(1-$ $10 \mathrm{~cm}), 2(11-20 \mathrm{~cm}), 3(21-30 \mathrm{~cm}), 4(31-40 \mathrm{~cm}), 5(41-50$ $\mathrm{cm}), 6(51-60 \mathrm{~cm}), 7(>60 \mathrm{~cm})$. Both species of cod were sampled so that all size classes were as evenly represented as possible. This came, however, with the expense of a non-random sample of the population. The smaller length groups $(0-3)$ are roughly equivalent to the age of the cod. In larger length groups this pattern becomes blurred due to overlapping of cohorts. Based on other studies in the area we estimate that the Atlantic cod and Greenland cod sampled were 1-7 years and 1-5 years, respectively (e.g., Storr-Paulsen and Wieland 2006).

\section{Parasite counts and identification}

In the visceral cavity of the fish, all anisakid nematodes visible to the naked eye were collected and counted, and the intensity was assigned to six categories: 0 (uninfected), 1 (1-5 ind.), 2 (5-10 ind.), 3 (10-20 ind.), 4 (20-30 ind.) or 5 (> 30 ind.). Because parasites can be present in the musculature, and thus not included in the counts, the intensity will be underestimated. However, the intensity found through the visual search will most likely be strongly correlated with the actual intensity, thus being adequate for the purpose of the present study.

For morphological identification in the laboratory, a subsample of maximum 17 individual nematodes were collected from each fish individual and preserved in 70\% ethanol in 1.8 $\mathrm{ml}$ Eppendorf tubes. 97 tubes with material from Atlantic cod and 38 from Greenland cod were chosen randomly. Appropriate techniques aiding the identification of parasites were applied. Nematodes were cut into three parts: the head and caudal part were used for morphological identification and cleared in lactophenol and embedded in glycerine-gelatine. The midpart of the nematodes was used for PCR-RLFP analysis and sequencing of the nuclear rDNA containing both ITS (Internal Transcribed Spacers) and gene 5.8S (D'Amelio et al. 2000, Kijewska et al. 2002, Pontes et al. 2005).

The primers NC5 (forward; 5'-GTAGGTGAACCTGCGGAAGGATCATT-3') and NC2 (reverse; 5'-TTAGTTTCTT TTCCTCCGCT-3') (Zhu et al. 1998) were used for amplification of the rDNA region containing entire ITS1, 5.8S rDNA gene and ITS2. PCR amplification was carried out in a volume 
of $50 \mu$ containing 100 pmol of each primer, 1x PCR buffer, $250 \mu \mathrm{M}$ of each dNTP (dATP, dCTP, dGTP, dTTP) (Fermentas, Lithuania), 1 U of DyNAzyme II DNA Polymerase (Finnzymes, Finland) and approximately $2 \mathrm{ng}$ of total isolated DNA. The PCR was performed under following conditions: initial denaturation at $95^{\circ} \mathrm{C}$ for $5 \mathrm{~min}, 30$ cycles of $30 \mathrm{~s}$ at $95^{\circ} \mathrm{C}$, $30 \mathrm{~s}$ at $57^{\circ} \mathrm{C}$ and $30 \mathrm{~s}$ at $72^{\circ} \mathrm{C}$, and final extension at $72^{\circ} \mathrm{C}$ for 5 min. PCR products $(5 \mu \mathrm{l})$ were digested with $1 \mathrm{U}$ of each restriction endonuclease (TaqI, RsaI, BsuRI, AluI, HinfI and HhaI) in a volume of $10 \mu \mathrm{l}$. The amplification and digestions products were separated by electrophoresis in respectively $1 \%$ routine use agarose (Sigma) and 4\% high resolution agarose (Sigma) gel stained with ethidium bromide $(10 \mathrm{mg} / \mathrm{ml})$ and visualized under UV light. Both spacers were sequenced in both orientations using the primer sets NC5, NC13 (reverse; 5'-ATCGATGAAGAACGCAGC-3'; Zhu et al. 1998) and NC2, Anc13 (forward; 5'-CTTAGTGCTCAATGTGTCTG3'; Kijewska et al. 2009). DNA sequencing was preformed by Macrogen Inc. (Korea).

\section{Stomach analysis}

The contents of the stomach were determined to the lowest possible taxonomic level and assigned to one of eleven prey categories (species or groups of species, see Table II). Following identification, the dry weight of each prey category was measured after $24 \mathrm{hrs}$ at $65^{\circ} \mathrm{C}$ after which no further weight loss took place. The composition of prey in the stomachs was expressed as prey-specific abundance $\left(\mathrm{A}_{\mathrm{W}}\right)$ :

$$
\mathrm{A}_{\mathrm{w}}=\left(\sum \mathrm{W}_{\mathrm{i}}\right)\left(\sum \mathrm{W}_{\mathrm{it}}\right)^{-1}
$$

where $\mathrm{W}_{\mathrm{i}}$ is the dry weight of prey in a given category and $\mathrm{W}_{\mathrm{it}}$ is the total dry weight of prey in the stomachs containing prey (Nielsen and Andersen 2001).

\section{Condition factor}

Simple condition indices (CF) were calculated as a proxy for energy reserve of the cod (e.g., Schwalme and Chouinard 1999, Storr-Paulsen et al. 2006), according to:

$$
\mathrm{CF}=100 \mathrm{~W} *\left(\left(\mathrm{~L}^{\mathrm{b}}\right)^{-1}\right)
$$

where $\mathrm{W}$ denotes the wet weight (g) excluding stomach content and $\mathrm{L}$ total length $(\mathrm{cm})$ of the fish. The exponent $\mathrm{b}$ denotes the regression coefficient between $\ln (\mathrm{W})$ and $\ln (\mathrm{L})$ across the entire species specific data set. The exponent $b$ in the calculations of CF was determined to be $3.0333\left(r^{2}=0.99\right)$ for Atlantic cod and $3.4013\left(r^{2}=0.98\right)$ for Greenland cod, which is in line with other investigations from West Greenland (Storr-Paulsen et al. 2006).

\section{Statistical analyses}

All analyses were carried out using SPSS (Statistical Package of Social Sciences). Standard parametric tests were preceded by test for assumptions. When these were violated, the data were either transformed $(\mathrm{ln})$ or non-parametric statistics were applied. Percentage data were arcsine-transformed if any values approached zero or $100 \%$. When mean values are given the associated variation is given as standard deviations (SD).

\section{Results}

$\operatorname{Sex}$

There was no gender specific difference in either the prevalence of anisakid nematodes (Fisher's exact test; $P=0.84$ ), the intensity of infected individuals $\left(\chi_{[4]}^{2}=6.82 ; P=0.15\right)$, or the condition factor (Student's t-test, $t_{191}=1.19 ; P=0.24$ ) of Atlantic cod. This holds true also for the two fiord systems considered separately (summary statistics not shown). Hence, since also very few Greenland cod were sexed, interactions with gender are disregarded in the further analysis of both species of cod.

\section{Nematode species and relative prevalence}

Based on the collected subsamples of nematodes from the visceral cavity of each caught gadid, Atlantic cod was found infected with third stage larvae (L3) of Contracaecum osculatum (Rudolphi, 1802), Anisakis simplex (Rudolphi, 1809) and Hysterothylacium aduncum (Rudolphi, 1802). Contracaecum osculatum was recorded in $73.9 \%$ of the subsamples (mean no. per subsample: 7.0, range: 1-17). Anisakis simplex was recorded in $24.2 \%$ of the samples (mean no. per subsample: 1.3 , range: 1-5). Hysterothylacium aduncum was found only in one subsample/fish (1.0\%). Greenland cod were found infected mainly by $C$. osculatum ( $84.3 \%$ of subsamples, mean no. per subsample: 6.8 , range: $1-15$ ) and $A$. simplex occurred in $8.3 \%$ of the samples (mean no. per sample: 1.7, range: 1-3).

Molecular analysis using PCR-RFLP technique and further sequencing of Internal Transcribed Spacers (ITS1 and ITS2) for both fish species revealed presence of two sibling species, C. osculatum B and C. osculatum $\mathrm{C}$, as well as one species from the $A$. simplex complex - A. simplex s.s.

\section{Overall parasite prevalence}

Based on the counts of worms at the point of fish collection, the prevalence of anisakid nematodes spp. was significantly higher in Atlantic cod from the Sisimiut fiord system (80\%) than from the Godthaab fiord system (66\%) (Fisher's exact test; $P=0.04)$. In contrast, the prevalence of anisakid nematode infections in Greenland cod did not differ between areas (Fisher's exact test; $P=0.41$ ) reaching $73 \%$ overall. As the mean fish length did not differ significantly between areas, neither regarding Atlantic cod (Student's t-test; $t_{225}=1.30 ; P=$ 0.20 ; overall mean $[\mathrm{SD}]=35.4[13.7] \mathrm{cm})$ nor Greenland cod (Student's t-test; $t_{62}=0.23 ; P=0.82$; overall mean $[\mathrm{SD}]=25.3$ $[8.4] \mathrm{cm})$, the observed pattern of prevalence is not a mere result of host size variation (see below). 

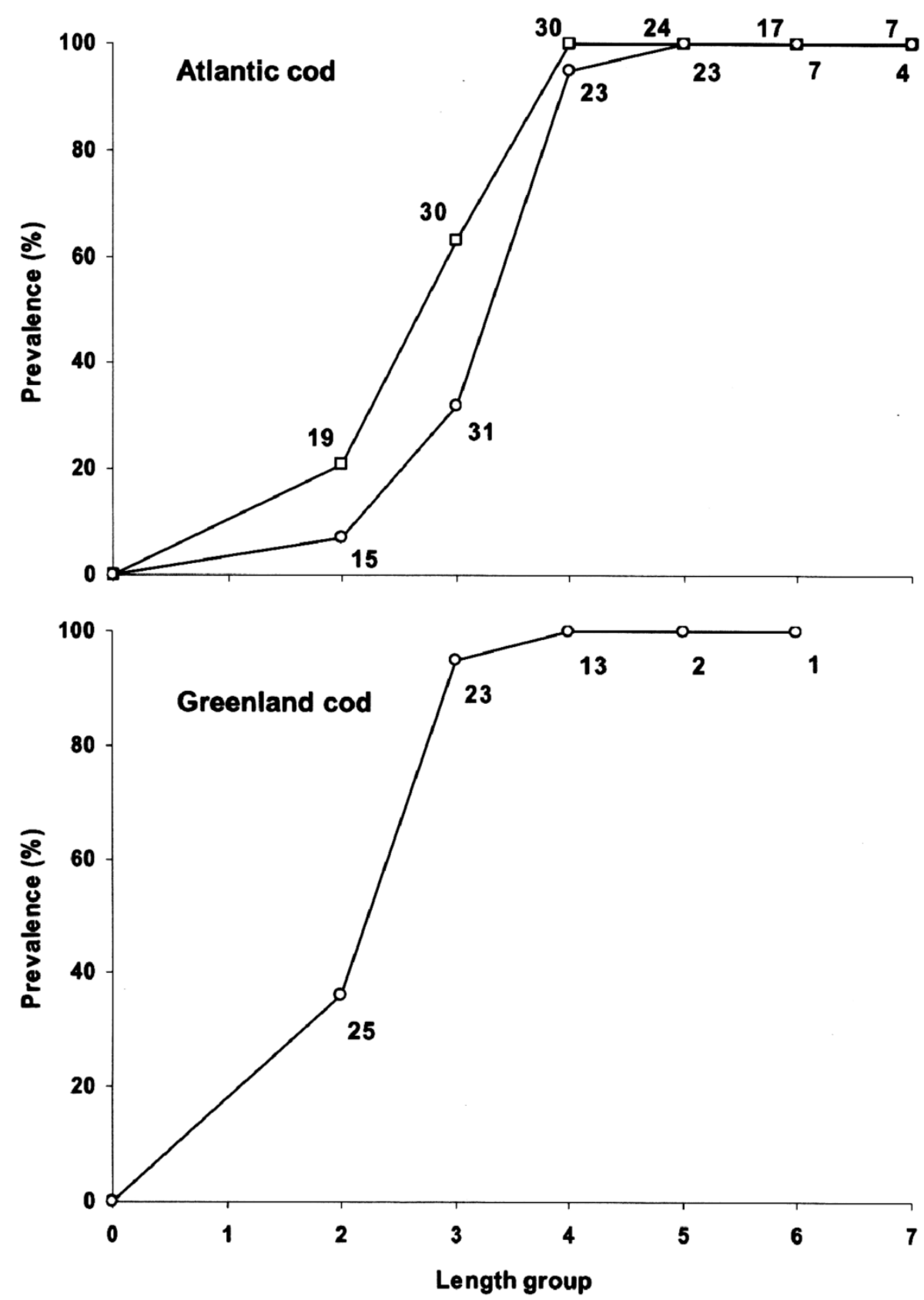

Fig. 1. The prevalence of anisakid nematodes in Atlantic cod (Gadus morhua) and Greenland cod (Gadus ogac) as a function of fish length (groups) from the Godthaab fiord system (०) and the Sisimiut fiord system ( $\square$ ) (forced through zero). For Greenland cod, the two areas are combined. Sample size is indicated for each data point. The length groups are 0: $0 \mathrm{~cm}, \mathbf{1}: 1-10 \mathrm{~cm}, 2: 11-20 \mathrm{~cm}, \mathbf{3 :} 21-30 \mathrm{~cm}$, 4: 31-40 cm, 5: 41-50 cm, 6: 51-60 cm, 7: > $60 \mathrm{~cm}$

For both species of cod, there was a significant prevalence-length relationship (Crosstabs; Atlantic cod: $\chi^{2}>59.19$; $P<0.0005$ for both areas; Greenland cod: $\chi_{[4]}^{2}=10.35 ; P=$ 0.035 for the Godthaab area; $\chi_{[3]}^{2}=20.50 ; P<0.0005$ for the Sisimiut area; Fig. 1). While the prevalence increases with length for both species, the prevalence reaches nearly $100 \%$ at a lower length for the Greenland cod $(21-30 \mathrm{~cm})$ than for the Atlantic cod (31-40 cm). Furthermore, the prevalence increases faster for the Atlantic cod in the Sisimiut area (reach- ing almost $100 \%$ in the $31-40 \mathrm{~cm}$ length group) than in the Godthaab area (were $100 \%$ was attained at $41-50 \mathrm{~cm}$ ). Generally, the increase in the proportion of infected individuals appears particularly rapid between size-classes $2-3$ and 3-4 (i.e., about $10-40 \mathrm{~cm}$ in length) (Fig. 1).

Although the sample size in some of the size-classes are relatively small (see Fig. 1), they are considered sufficiently large for a robust evaluation of the overall relationship between prevalence of infection and host length (see Wilson et al. 2004). 


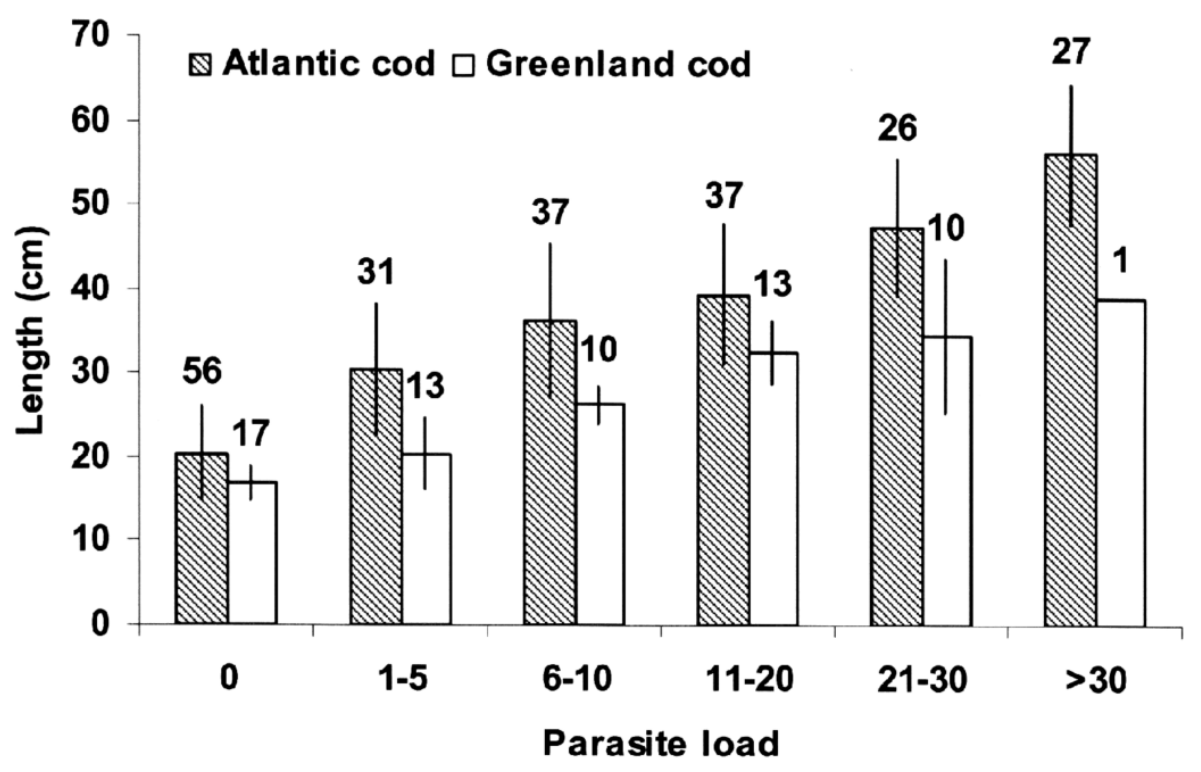

Fig. 2. The mean length ( \pm SD) of Atlantic cod (Gadus morhua) and Greenland cod (Gadus ogac) according to intensity of infection/parasite load (number of anisakid nematodes per host individual). Sample size is given for each intensity category

\section{Parasite intensity}

No significantly difference in overall intensity could be demonstrated between fiord systems for either host species (Crosstabs; Atlantic cod: $\chi^{2}{ }_{[5]}=7.18 ; P=0.21$; Greenland cod: $\left.\chi_{[3]}^{2}=1.27 ; P=0.74\right)$, and hence, data from the two areas were pooled in order to analyse the relationship between host size and intensity. A strong positive relationship was found between fish length and parasite intensity for both Atlantic cod (Oneway ANOVA; $\left.F_{5,210}=96.78 ; P<0.0005\right)$ and Greenland cod (Kruskal-Wallis test; $\chi_{[4]}^{2}=48.06 ; P<0.0005$ ) (Fig. 2). However, a given intensity was attained at a lower size by Greenland than by Atlantic cod; that is, for a given length, Greenland cod are on average more heavily infected than Atlantic cod.

Although the length-parasite intensity relationships appear approximately linear for both species of host, they are not, and follow from the use of uneven intensity intervals (Fig. 2). Applying break-point linear regressions on the data (as the best fitting model) that include fish length as dependent variable and the mid point of each intensity interval as independent variable, demonstrate a significantly larger slope for the smallest intensities ( $0-2.5$ nematodes per host) than for larger intensities (2.5-25) (Table I). This suggests that the parasites accumulate steadily but at a slower rate in smaller fish (ca. 20-30 $\mathrm{cm}$ in length for Atlantic cod) than in larger fish (ca. 30-55 cm, Atlantic cod) (see Fig. 2 for length intervals of Greenland cod).

\section{Diet and parasite intensity}

Capelin was in this study estimated as the most important prey species, making up $70 \%$ of the total stomach dry weight in Atlantic cod and 93\% in Greenland cod (Table II). Furthermore, the stomach content of the Greenland cod contains fewer prey species than the Atlantic cod as only six of the eleven recorded prey categories were represented. Besides capelin, only one of these six categories constitutes more than $1 \%$ of the total dry weight indicating a capelin targeted diet. In contrast, only two prey categories for the Atlantic cod constituted less than $1 \%$. However, the feeding of the individual fish does not all follow this overall pattern. Small prey items such as small crustaceans and capelin eggs are particularly important to cod in length-group $2(11-20 \mathrm{~cm})$, whereas the occurrence of such prey in the stomachs rapidly decreases on the expense of capelin in larger fish (Atlantic cod: $r_{\mathrm{s}}=-0.55 ; P<$ 0.0005; Greenland cod: $r_{\mathrm{s}}=-0.57 ; P<0.0005$ ) (Fig. 3). This pattern was especially pronounced in Greenland cod.

The different prey items are not evenly important as a source of anisakid infections. Hence, in order to investigate the relationship between prey choice at the point at capture (taken as a proxy of general feeding behaviour) and nematode infection intensity, the fish were paired (at random) according to length $( \pm 1 \mathrm{~cm})$ and whether or not they have preyed on capelin (either no capelin or exclusively capelin in the stomach), and analysed for difference in intensity. Regarding Atlantic cod, no statistical difference was evident for the entire length range (Wilcoxon signed ranks test; $Z=1.159 ; n=48$; $P=0.11)$. However, focusing on intermediate sized fish (27$55 \mathrm{~cm}$ ) (thereby excluding both the smaller mostly uninfected and the larger all heavily infected individuals), those that have preyed exclusively on capelin harboured significantly more anisakid nematodes than those that have preyed exclusively on other food items (Wilcoxon signed ranks test; $Z=2.126 ; n=$ $37 ; P=0.033)$. A similar pattern was found in Greenland cod over the entire range of fish length available $(13-51 \mathrm{~cm})$ using one-tailed test (Wilcoxon signed ranks test; $Z=1.706 ; n=$ $15, P=0.044)$. The use of one-tailed test can here be justified 
Table I. Summary statistics from linear regressions and ANCOVA* including the length of Atlantic cod (Gadus morhua) and Greenland cod (Gadus ogac) as the dependent variable, mid-points of parasite intensity intervals (number of anisakid nematodes per host individual) as dependent variable, and two intensity ranges as separating factor. Note that a large slope indicate a slow accumulation of nematodes for a given host size increment

\begin{tabular}{|c|c|c|c|c|}
\hline \multirow[b]{2}{*}{ Parameter } & \multicolumn{2}{|c|}{ Parasite intensity } & \multirow[b]{2}{*}{$F^{*}$} & \multirow[b]{2}{*}{$P^{*}$} \\
\hline & $0-2.5$ & $2.5-25$ & & \\
\hline \multicolumn{5}{|l|}{ Atlantic cod } \\
\hline Slope & 3.97 & 0.84 & 22.21 & $<0.0005$ \\
\hline SE & 0.57 & 0.07 & & \\
\hline $\mathrm{F}$ & 0.60 & 0.70 & & \\
\hline $\mathrm{P}$ & $<0.0005$ & $<0.0005$ & & \\
\hline Df & 35 & 158 & & \\
\hline \multicolumn{5}{|c|}{ Greenland cod } \\
\hline Slope & 1.38 & 0.64 & 10.69 & 0.002 \\
\hline $\mathrm{SE}$ & 0.46 & 0.09 & & \\
\hline $\mathrm{F}$ & 0.49 & 0.72 & & \\
\hline $\mathrm{P}$ & 0.006 & $<0.0005$ & & \\
\hline Df & 28 & 45 & & \\
\hline
\end{tabular}

*ANCOVA interaction-term evaluating difference in slope.

because the tendency was established in a two-tailed test on the independent sample of Atlantic cod.

\section{Condition factor}

Pooling the data from the two localities allowed a Two-way ANOVA investigating the effect of prey choice (capelin vs no capelin in the stomach at capture) and parasite intensity, and their interactions, on the condition factor of the Atlantic cod. No interaction was evident $\left(F_{5,204}=0.923 ; P=0.47\right)$ and the reduced model demonstrated no effect of parasite intensity on the condition factor $\left(F_{5,209}=0.36 ; P=88\right)$, but a significantly higher condition of fish that had eaten capelin $(5 \%$, based on grand means) than of fish that had not $\left(F_{1,209}=4.262 ; P=0.04\right)$. A similar Two-way analysis could not be carried out on Greenland cod. However, no overall effect of either parasite intensity (One-way ANOVA; $F_{5,58}=0.923 ; P=0.47$ ) or presence/absence of capelin in the stomach (Student's t-test, $t_{62}=$ $1.225 ; P=0.23$ ) could be demonstrated on the condition factor of Greenland cod. Albeit non-significant, the condition factor of Greenland cod was (as also seen for Atlantic cod) averagely 5\% higher among capelin-eating fish than among fish that had not been eating capelins prior to capture.

\section{Discussion}

\section{Nematode prevalence and intensity}

Disregarding discrepancies that can be ascribed to variation in methodology, the nematode prevalence and intensity recorded here in Atlantic cod is generally in agreement with values ob- served also in waters off northern Canada and Norway (Brattey and Bishop 1992, Boily and Marcogliese 1995, Hemmingsen et al. 2000). Regarding parasite prevalence there was a tendency of regional variation, in that Atlantic cod appeared to become more quickly infected in the Sisimiut area than in the Godthaab area. Similar geographical variation has been observed off Canada, and may in part reflect the distribution of the phocid and cetacean definitive hosts (McClelland et al. 1983, Brattey and Bishop 1992, Boily and Marcogliese 1995, McClelland 2002). However, it is difficult to quantify this difference and it is at present impossible to evaluate if the distribution of definitive hosts, which determines nematode composition in this area, influences parasite accumulation in the species studied here.

However, at any given length, Greenland cod were more likely to be infected, and harboured more parasite individuals, than similar sized Atlantic cod. This pattern may be governed in part by the different feeding behaviour of the two species of cod (see discussion below), and in part by their different lifehistory. Greenland cod is a more slow-growing species and will at a given length be older than a similar sized Atlantic cod (Nielsen 1992) and therefore have had more time to accumulate parasites.

\section{Diet and nematode infections}

In the vast majority of host-parasite systems, parasitism is observed to increase with the size/age of the host (regarding fish, see e.g., Polyanskiy 1958, Poulin 2000). The present study is no exception as both nematode prevalence and intensity increased with the length of the cod. Because anisakid nematodes often are long-lived (several years) (Strømnes and Andersen 2002) and hence particularly prone to accumulate over time (Brattey and Bishop 1992; McClelland 2002), such relationship is to be expected. However, the relationship is clearly non-linear, showing a rapid increase in nematode prevalence as well as the rate of parasite accumulation in both species of cod around size class 2-4 (Figs 1 and 2, Table II). Such dramatic size/age dependent increase in anisakid infestations, which is not common case in fish-parasite associations (Poulin 2000), has been observed also in other cod populations (McClelland 2002), and would not be expected if the nematode accumulation is solely a matter of time (see Grenfell and Dobson 1995). The pattern may be explained by the size/agedependent feeding behaviour of the cod, in which both species appear to undergo an ontogenetic shift in diet: the smaller fish eat almost no capelins but when the fish reach length group 2 (ca. $21-30 \mathrm{~cm}$ in length) and above, the diet is comprised of an ever increasing share of capelin (Fig. 3). Since the encountered anisakid nematodes can use capelin as a paratenic host (Marcogliese et al. 1996, Hays et al. 1998, Ólafsdottir and Hauksson 1998) that accumulates the larval nematodes by preying on small crustaceans used as first intermediate host (e.g., euphausiids and mysids), cod feeding on capelin will be exposed to a substantially higher risk of becoming infected than cod ex- 


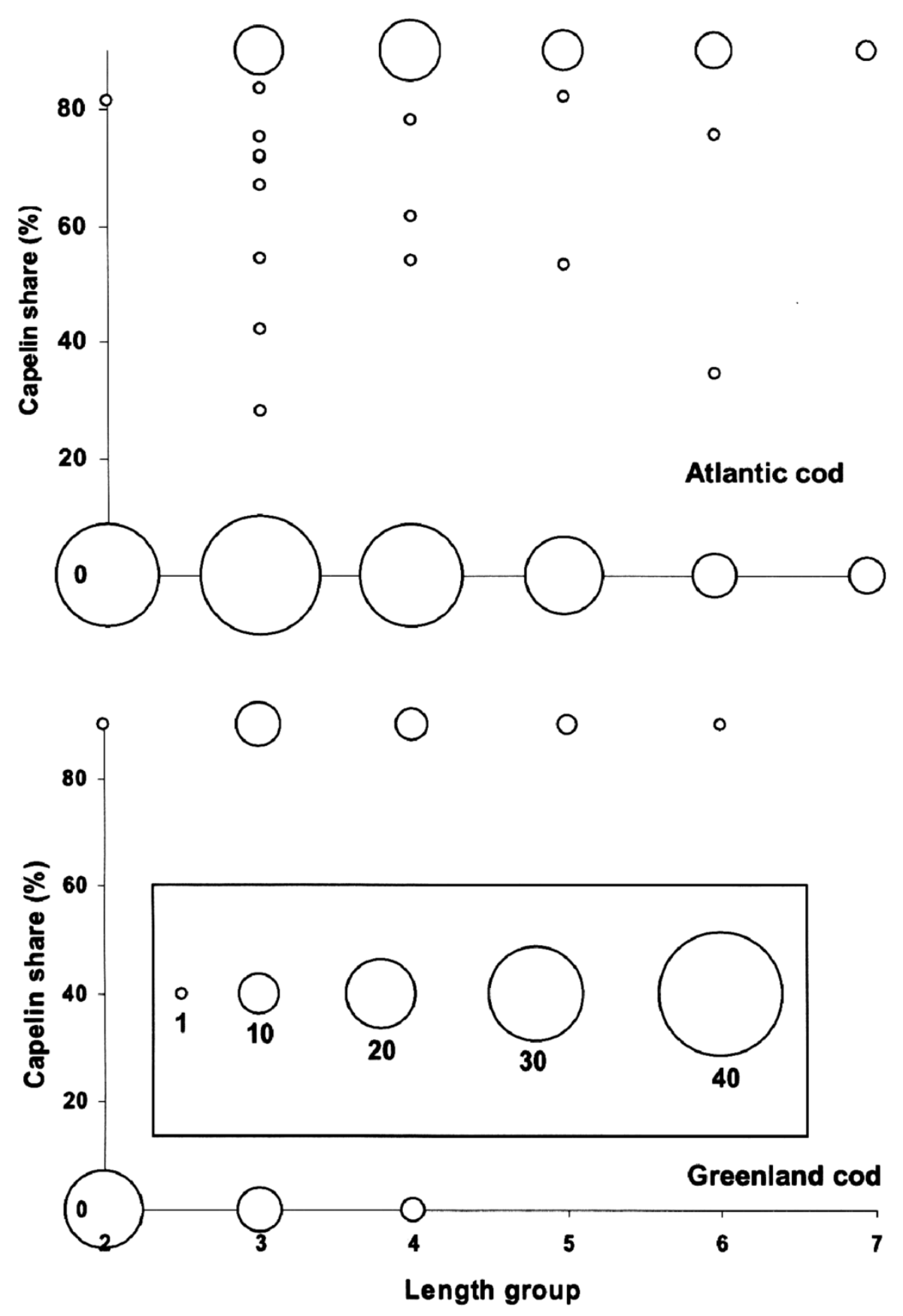

Fig. 3. The proportion (\% wet weight) of capelin (Mallotus villosus) eaten by Atlantic cod (Gadus morhua) and Greenland cod (Gadus ogac) according to fish length categories (see text to Fig. 1 for a key to size classes). The different sized circles indicate sample size, i.e. the number of collected fish having the proportion of capelin in their stomachs given on the y-axis. The key to sample size is given in the frame in the lower panel (Greenland cod) and apply to both the Atlantic cod and the Greenland cod panel. Data from Godthaab and Sisimiut are combined

isting on a diet of smaller prey items. The intensity of larval nematodes is very low in the crustacean first intermediate host (McClelland 2002). This scenario cooperates well with the here observed tendency of more heavy infections among capelin-eating cod than among fish that had not preyed upon capelin immediately prior to capture. Similar correlation in cod populations has been reported also by McClelland et al. (1983). Køie and Fagerholm (1995) reported that the newly hatched Contracae- cum osculatum larvae were capable of infecting small fishes only. Larger fishes could be infected only via the already infected crustaceans or small fishes. We here assume that the stomach content of the individual fish at the point of collection represents its regular diet also over a longer time span. This is, however, not necessarily the case. For the anisakid analysis, a short period of cod prey investigation (Table II) is useful only for preliminary information of the sources of infection. 
Table II. Prey categories (species and groups of species) encountered in the stomachs of Atlantic cod (Gadus morhua) and Greenland cod (Gadus ogac). For each species of cod, the prey-specific abundance using dry weight $\left(\mathrm{A}_{\mathrm{W}}\right)$ is calculated, which indicates the relative importance of a given prey category. For calculations see Materials and methods

\begin{tabular}{lcc}
\hline & \multicolumn{2}{c}{$\mathbf{A}_{\mathbf{w}}(\mathbf{\%})$} \\
\hline Prey category & Atlantic cod & Greenland cod \\
\hline $\begin{array}{l}\text { Euphausiidae spp. (krill) } \\
\text { Pandalus borealis (deepwater prawn) }\end{array}$ & 1.27 & 0.52 \\
Lebbeus polaris (polar lebbeid) & & \\
Chionoecetes opilio (snowcrab) & 7.81 & 0.43 \\
Hyas araneus (sandcrab) & & \\
Asteroidae spp. & 1.25 & 0.00 \\
Mallotus villosus (capelin) & 69.63 & 0.75 \\
Crustacea spp. & 0.64 & 0.76 \\
(mainly amphipods and juvenile crabs) & & 5.02 \\
Unidentified species & 2.67 & 0.00 \\
Mallotus villosus (capelin) eggs & 1.77 & 0.53 \\
Polychaeta spp. & 2.06 & 0.00 \\
Pholis gunnellus (butterfish) & 10.47 & 0.00 \\
Gonatus sp. (squid) & 0.81 & 0.00 \\
Cottidae spp. (sculpins) & 1.63 & \\
\hline
\end{tabular}

Of the two cod species investigated in this study, Greenland cod is more specialized on capelin, having a diet comprised of 93\% capelin as opposed to $70 \%$ in Atlantic cod (Table II). This may also contribute to the significantly higher parasite prevalence and intensity in Greenland cod than in Atlantic cod for any given length. This is an aspect to consider if the Greenland cod is to be targeted commercially as an alternative to the decimated population of Atlantic cod (Storr-Paulsen and Wieland 2006).

\section{Condition factor, diet, parasitism and molecular identification}

Both species of cod do not appear to suffer any reduction in condition factor with increasing infection intensity (see Results, condition factor). This may be the case because capelin beside of being a main source of parasites also represents the best choice of prey in terms of energy content (Montevecchi and Piatt 1984, Lawson et al. 1998). Rose and O'Driscoll (2002) have even suggested that Atlantic cod are unable to successfully reproduce without access to a diet containing capelin, and the present results show in concert that Atlantic cod preying on capelin are in better condition than individuals that have not.

In the North-West Atlantic, the sibling species Contracaecum osculatum B and C are found in the seal Halichoerus grypus, and C. osculaturn B has been noticed also in Phoca vitulina, Pagophilus groenlandicus and Cystophora cristata. Anisakix simplex s.s. from this area are reported from the whale Delphinapterus leucas and the fish Salmo salar and Scomberesox saurus (Mattiucci and Nascetti 2008). Present investigations show that in West Greenland waters, including both fiord systems, Godthaab and Sisimiut, anisakids use Greenland and Atlantic cod as a second or paratenic host to reach their marine mammal final host.
Acknowledgements. We wish to thank the Greenland Institute of Natural Resources for both financial and logistic support as well as manuscripts comments. Especially support from Lars Heilmann and Jonathan Carl from the Greenland Institute of Natural Resources is much appreciated. Economically, the study was partly financed by the University of Aarhus, the University of Copenhagen, and the Polish Ministry of Education and Science grant no. 1180/IPY/2007/01.

\section{References}

Arthur J.R., Albert E., Boily F. 1995. Parasites of capelin (Mallotus villosus) in the St. Lawrence estuary and Gulf. Canadian Journal of Fisheries and Aquatic Sciences, 52, 246-253.

Begon M., Harper J.L., Townsend C.R. 1996. Ecology: individuals, populations and communities. Blackwell Science, Oxford, UK, $106 \mathrm{pp}$.

Boily F., Marcogliese D.J. 1995. Geographical variations in abundance of larval anisakine nematodes in Atlantic cod (Gadus morhua) and American plaice (Hippoglosoides platessoides) from the Gulf of St. Lawrence. Canadian Journal of Fisheries and Aquatic Sciences, 52, 105-115.

Brattey J., Bishop C.A. 1992. Larval Anisakis simplex (Nematoda: Ascaridoidea) infection in the musculature of Atlantic cod, Gadus morhua, from Newfoundland and Labrador. Canadian Journal of Fisheries and Aquatic Sciences, 49, 2635-2647.

Dogiel V.A. 1958. Ecology of the parasites of freshwater fishes. In: (Eds. V.A. Dogiel, G.K. Petrushevskiy and Yu.I. Polyanskiy) Parasitology of Fishes. Trans. Z. Kabata, 1961. Oliver and Boyd, Edinburgh and London, 1-47.

D’Amelio S., Mathiopoulos K.D., Santos C.P., Pugachev O.N., Webb S.C., Picanço M., Paggi L. 2000. Genetic markers in ribosomal DNA for the identification of members of the genus Anisakis (Nematoda: Ascaridoidea) defined by polymerase chain reaction - based restriction fragment length polymorphism. International Journal for Parasitology, 30, 223-226. DOI: 10.1016/S0020-7519(99)00178-2.

Grenfell B.T., Dobson A.P. 1995. Ecology of infectious diseases in natural populations. Oxford University Press, Oxford, UK, 533 pp. 
Hays R., Measures L.N., Huot J. 1998. Capelin (Mallotus villosus) and herring (Clupea harengus) as paratenic hosts of Anisakis simplex, a parasite of beluga (Delphinapterus leucas) in the St. Lawrence Estuary. Canadian Journal of Zoology, 76, 14111417. DOI: $10.1139 /$ cjz-76-8-1411.

Hemmingsen W., Halvorsen O., MacKenzie K. 2000. The occurrence of some metazoan parasites of Atlantic cod, Gadus morhua L., in relation to age and sex of the host in Balsfiord $\left(70^{\circ} \mathrm{N}\right)$, North Norway. Polar Biology, 23, 368-372. DOI: 10.1007/S0 03000050457

Hemmingsen W., MacKenzie K. 2001. The parasite fauna of the Atlantic cod, Gadus morhua L. Advances in Marine Biology, 40, 1-79. DOI: 10.1016/S0065-2881(01)40002-2.

Khan R.A., Chandra C.V. 2006. Influence of climatic changes on the parasites of Atlantic cod Gadus morhua off coastal Labrador, Canada. Journal of Helminthology, 80, 193-197. DOI: $10.1079 / \mathrm{JOH} 2006352$

Kijewska A., Dzido J., Shukhgalter O., Rokicki J. 2009. Anisakid parasites of fishes caught on the African shelf. Journal of Parasitology, 95, 639-645. DOI: 10.1645/GE-1796.1.

Kijewska A., Rokicki J., Sitko J., Węgrzyn G. 2002. Ascaridoidea: a simple DNA assay for identification of 11 species infecting marine and freshwater fish, mammals, and fish-eating birds. Experimental Parasitology, 101, 35-39. DOI: 10.1016/S00 14-4894(02)00031-0.

Køie M., Fagerholm H.P. 1995. The life cycle of Contracaecum osculatum (Rudolphi, 1802) sensu stricto (Nematoda, Ascaridoidea, Anisakidae) in view of experimental infections. Parasitology Research, 81, 481-489.

Lawson J.W., Magalhaes A.M., Miller E.H. 1998. Important prey species of marine vertebrate predators of the northwest Atlantic: proximate composition and energy density. Marine Ecology Progress Series, 164, 13-20. DOI: 10.3354/meps 16 4013.

Link J.S., Garrison L.P. 2002. Trophic ecology of Atlantic cod Gadus morhua on the northeast US continental shelf. Marine Ecology Progress Series, 227, 109-123. DOI: 10.3354/meps22 7109.

Marcogliese D.J., Boily F., Hammill M.O. 1996. Distribution and abundance of stomach nematodes (Anisakidae) among grey seals (Halichoerus grypus) and harp seals (Phoca groenlandica) in the Gulf of St. Lawrence. Canadian Journal of Fisheries and Aquatic Sciences, 53, 2829-2836. DOI: 10.11 39/cjfas-53-12-2829.

Mattiucci S., Nascetti G. 2008. Advances and trends in the molecular systematics of anisakid nematodes, with implications for their evolutionary ecology and host-parasite co-evolutionary processes. Advances in Parasitology, 66, 47-148. DOI: 10. 1016/S0065-308X(08)00202-9.

McClelland G. 2002. The trouble with sealworms (Pseudoterranova decipiens species complex, Nematoda): a review. Parasitology, 124, 183-203. DOI: 10.1017/S0031182002001658.

McClelland G., Misra R.K., Marcogliese D.J. 1983. Variations in abundance of larval anisakines, sealworm (Phocanema decipiens) and related species in cod and flatfish from the southern Gulf of St. Lawrence (4T) and the Breton Shelf (4Vn). In: Canadian Technical Report of Fisheries and Aquatic Sciences, Dept. Fisheries and Oceans, Ottawa, No. 1201.

Montevecchi W.A., Piatt J.F. 1984. Composition and energy contents of mature inshore spawning capelin (Mallotus villosus): implications for seabird predators. Comparative Biochemistry and Physiology, 78, 15-20. DOI: 10.1016/0300-9629(84)90 084-7.
Mouritsen K.N., Poulin R. 2002. Parasitism, community structure and biodiversity in intertidal ecosystems. Parasitology, 124, S101-S118. DOI: 10.1017/S0031182002001476.

Møller A.P. 2005. Parasitism and the regulation of host populations. In: (Eds. F. Thomas, F. Renaud and J.F. Guégan) Parasitism \& Ecosystems. Oxford University Press, Oxford, 43-53.

Nielsen J.R. 1992. Growth of Greenland cod, Gadus ogac, in the Nuuk area of West Greenland. ICES Committee Meetings Documents, CM 1992(G:32), International Council for the Exploration of the Sea, Copenhagen, $12+7 \mathrm{pp}$. Annexes.

Nielsen J.R, Andersen M. 2001. Feeding habits and density patterns of Greenland cod, Gadus ogac (Richardson 1836), at West Greenland compared to those of the coexisting Atlantic cod, Gadus morhua L. Journal of Northwestern Atlantic Fisheries Science, 29, 1-22. DOI: 10.2960/J.v29.a1.

Ólafsdottir D., Hauksson E. 1998. Anisakid nematodes in the common seal (Phoca vitulina L.) in Icelandic waters. Sarsia, 83, 309-316.

Polyanskiy Y.I. 1958. Ecology of parasites of marine fishes. In: (Eds. V.A. Dogiel, K. Petrushevskiy and Y.I. Polyanskiy) Parasitology of fishes. Leningrad University Press, Leningrad, 48 83 (In Russian).

Pontes T., D'Amelio S., Costa G., Paggi L. 2005. Molecular characterization of larval anisakid nematodes from marine fishes of Madeira by a PCR-based approach, with evidence for a new species. Journal of Parasitology, 91, 1430-1434. DOI: 10.1645/GE-565R1.1.

Poulin R. 2000. Variation in the intraspecific relationship between fish length and intensity of parasitic infection: biological and statistical causes. Journal of Fish Biology, 56, 123-137. DOI: 10.1111/j.1095-8649.2000.tb02090.x.

Rokicki J. 2006. Anisakidoza. In: (Ed. A. Kotłowski) Medycyna i Higiena Tropikalna. AMG, Gdańsk, 488-494 (In Polish).

Rose G.A., O'Driscoll R.L. 2002. Capelin are good for cod: can the northern stock rebuild without them? ICES Journal of Marine Science, 59, 1018-1026. DOI: 10.1006/jmsc.2002.1252.

Schwalme K., Chouinard G.A. 1999. Seasonal dynamics in feeding, organ, weights and reproductive maturation of Atlantic cod (Gadus morhua) in the southern Gulf of St. Lawrence. ICES Journal of Marine Science, 56, 303-319. DOI: 10.1006/jmsc. 1999.0458.

Storr-Paulsen M., Wieland K. 2006. Den Atlantiske torsk i de grønlandske farvande 2005. Teknisk rapport nr. 63, Pinngortitaleriffik, Grønlands Naturinstitut, Nuuk.

Storr-Paulsen M., Carl J., Wieland K. 2006. The importance of Atlantic Cod (Gadus morhua) predation on Northern Shrimp (Pandalus borealis) in Greenland waters 2005. NAFO/ICES WG Pandalus Meeting - October/November 2006. NAFO SCR Doc. 06/68, 16 pp.

Strømnes E., Andersen K. 2002. Growth of whaleworm (Anisakis simplex, Nematoda, Ascaridoidea, Anisakidae) third-stage larvae in paratenic fish hosts. Parasitology Research, 89, 335-341.

Wilson K., Bjørnstad O.N., Dobson A.P., Merler S., Poglayen G., Randolph S.E., Read A.F., Skorping A. 2004. Heterogeneities in macroparasite infections: patterns and processes. In: (Eds. J. Hudson, A. Rizzoli, B.T. Grenfell, H. Heesterbeek and A.P. Dobson) The ecology of wildlife diseases. Oxford University Press, Oxford, 6-44.

Zhu X.Q., Gasser R.B., Podolska M., Chilton N.B. 1998. Characterisation of anisakid nematodes with zoonotic potential by nuclear ribosomal DNA sequences. International Journal for Parasitology, 28, 1911-1921. DOI: 10.1016/S0020-7519(98) 00150-7. 